\title{
CANTILEVERED VERSUS NON-CANTILEVERED RESILIENT BAR ATTACHMENT FOR 2-IMPLANT RETAINED MANDIBULAR OVERDENTURES. A SHORT TERM CROSSOVER STUDY OF CHEWING EFFICIENCY AND BITE FORCE
}

\author{
Waleed Hamed Maryod* and Dina Bahgat El Talawy**
}

\begin{abstract}
Aim of the study: This study compared chewing efficiency and maximum bite force between Cantilevered and non-cantilevered resilient bar attachment used for 2-implant retained mandibular overdentures.

Materials and methods: Eight complete denture wearers (4 men, 4 women) complaining from mandibular dentures with atrophied mandibular ridges received 2 implants in the canine region. After 3 months, each patient received Hader bar with $7 \mathrm{~mm}$ distal cantilevers and mandibular overdentures with 3 clips (CHB group). After another 3 months, distal cantilevers were sectioned and patients received Hader bar without cantilevers and mandibular overdentures with one clip (HB). Chewing efficiency (using unmixed fraction (UF) in a colored gum) and bite force were measured 3 months after using their exsisting conventional dentures (CD), CHB, and HB.
\end{abstract}

Results: The highest unmixed Fraction (UF) was noted with 5 cycles and the lowest number was noted with 50 cycles. UF decreased with the increase of number of chewing strokes. For all chewing strokes, the highest UF was noted with $\mathrm{CD}$, followed by HB, and the lowest UF was noted with CHB. At 30 and 50 strokes, there was a significant difference between each 2 groups, and $\mathrm{HB}$ showed significant higher UF than CHB. The highest maximum bite force was noted with CHB, followed by $\mathrm{HB}$, and the lowest was noted with $\mathrm{CD}$.

Conclusion: Within the limitations of this study, it could be concluded that both cantilevered and non-cantilevered bar attachments for 2 implant overdentures achieved higher chewing efficiency and maximum bite force than conventional dentures in patients with atrophied mandibular ridges. However, cantilevered bar was associated with significant higher chewing efficiency and maximum bite force compared to non-cantilevered bar.

* Associate Professor, Department of Removable Prosthodontics, Faculty of Dentistry, Modern Science and Arts University (MSA), Egypt.

** Associate Professor, Department of Removable Prosthodontics, College of Oral and Dental Surgery, Misr University for Science and Technology, Egypt. 


\section{INTRODUCTION}

Edentulous individuals with resorbed mandibles usually have problems with conventional dentures because of impaired load-bearing capacity ${ }^{1}$ such as pain during mastication, insufficient stability, and retention ${ }^{2}$. Two-implant retained mandibular overdentures are standard routine therapy for such patients as stated in the McGill consensus in $2002^{3}$ and the York Consensus in $2009^{4}$. Different anchor systems may be used for these overdentures and are categorized as splinted or unsplinted. The splinted systems are the bar attachments while the unsplinted systems comprise ball anchors, magnets, resilient telescopic crowns, or stud-type attachments 5 . For atrophied jaws, a connector that provides a considerable amount of horizontal stability as barand parallel-walled telescopic crowns are indicated ${ }^{6}$. Splinting (bar attachments have several merits as splinting the implants, load and stress sharing between implants ${ }^{7}$, resistance to lateral loads $^{8}$, improved denture stability ${ }^{9}$, achieving good primary splinting, and reduction of micromotion at the bone-implant interface especially with immediately loaded implants..$^{10}$ Moreover bar attachments can be used with non-parallel implants, has greater retention and fewer prosthetic complications than other attachments (such as ball, and Locator attachments) ${ }^{7}$. However, bar and clip attachments need more restorative space, are initially more expensive, and are technically more complex than stud attachments. ${ }^{11,12}$ It also needs sufficient space between the bar and the mucosa to facilitate oral hygiene. Frederick and Caputo ${ }^{13}$ stated that; spaced oval (Dolder) or round (Hader) bar joints allow both vertical and rotational movements. The Hader bar system is only $3 \mathrm{~mm}$ high with a total height that is less than the Dolder bar. It has a round superior aspect and an apron toward the tissue below. It consists of a keyhole-shaped male bar resin pattern, and female nylon rider clip ${ }^{14}$. It has several advantages as ease of replacement of plastic clips if retention decreased which is less expensive and reduced the wear of the metal bar than metal clips ${ }^{15}$.
The traditional design of bar attachment joining the 2 implants in the mandible is the use of one bar parallel with the hinge axis to allow free rotation of the denture around the bar without load transmission to the implants ${ }^{16,17}$. However, this free rotation may increase posterior mandibular ridge resorption ${ }^{18}$. Therefore, in several studies ${ }^{19-23}$, the authors recommended the addition of two short distal cantilevers to the bar to increase the denture support, retention, and stability. Moreover, this design minimizes denture rotation and posterior ridge resorption. The increased rigidity of such overdentures stabilizes the occlusion and reduces the number of prosthodontic complications ${ }^{24}$. The enhanced denture support by this design reduces tissue irritation, protects sharp mylohyoid ridge ${ }^{25}$. In cases of knife-edge ridge or chronic mucosal soreness, the increased denture support decreases the loading of the tissues and minimizes patient discomfort ${ }^{26}$.

Theoretically, when two implants are connected with a cantilevered bar, the prosthesis shows less movement, and moment forces may be increased on implants ${ }^{27}$ especially when the occlusal resiliency in the clip did not compensate for oral mucosa resiliency ${ }^{9}{ }^{28}$. However, in the clinical setting, distal cantilevers on 2 implants do not influence the stability of clinical parameters, peri-implant bone loss or implant survival ${ }^{29}$. In another invitro study, the authors reported that the optimum length of the distal cantilevers should be $7 \mathrm{~mm}$ when 2 implants were used to support mandibular overdentures as it showed the lowest peri-implant strains ${ }^{22}$.

Implant stabilized overdentures were reported to increase maximum bite force, chewing efficiency, and patient satisfaction compared to conventional dentures ${ }^{30}$. Chewing efficiency was evaluated using several methods such as sizes of chewed particles $^{31}$, chewing time, numbers of chewing cycles ${ }^{32,33}$, sieving method, and two-color chewing gum $^{34,35}$. The improvement of chewing efficiency 
may depend on the type of retention mechanism ${ }^{36,37}$. Different types of bars provide varying degrees of retention and stability which may affect masticatory efficiency. Reviewing the literature, the effect of cantilevered bar connecting 2 implants on the masticatory efficiency and bite force of mandibular overdentures were not evaluated. Therefore, the present study aimed to evaluate chewing efficiency and bite force with cantilevered and noncantilevered resilient bar attachment for 2-implant retained mandibular overdentures.

\section{MATERIALS AND METHODS}

\section{Patient selection and study design}

Eight complete denture wearers (4 men, 4 women) participated in this study. Patients were included if they had the following criteria; 1) atrophied mandibular ridges with sufficient height and width to receive implants of at least $11 \mathrm{~mm}$ in height and $3.7 \mathrm{~mm}$ in width. This was checked by preoperative Cone Beam computerized tomography. 2) Patients complained of a lack of retention and stability of their conventional mandibular denture and needed to stabilize the dentures with dental implants. The following patients were excluded; 1) patients with bone metabolic disorders such as diabetes mellitus or hyperparathyroidism, 2) patients with neuromuscular disorders, 3) smokers, 4) patients with radiation therapy to head region, and 5) uncooperative patients. Informed written consent was obtained from all patients after explaining the protocol and objectives of the study. The protocol of the study was approved by the ethical committee of the faculty. The study was conducted using cross over study design, i.e., each participant acted as a control for himself (the same patient received several types of prostheses). At first, chewing efficiency and maximum bite force were measured for the existing complete denture (control, CD). Then each patient received 2 implants in the canine areas of the mandible. After 3 months, each patient received Hader bar with cantilevers (CHB group) and mandibular overdentures with 3 clips, and chewing efficiency and maximum bite force measurements were measured after 3 months. Then the participants received Hader bar without cantilevers $\mathrm{HB}$ and mandibular overdentures with one clip, and chewing efficiency and maximum bite force were repeated after three months of adaptation.

\section{Surgical and prosthetic procedures}

The mandibular denture was duplicated into heat cure clear acrylic resin with metal tubes attached to proposed implant sites to be used as a surgical and radiographic guide. Crestal incision was made and mucoperiosteum flap was elevated from the premolar area on one side to the premolar area on the other side. If needed, bone reshaping was made using crestal osteotome. Two implants (13x3.7mm, Tiologic, Dentaurum, Germany) were installed in the canine region of the mandible using a conventional 2-stage surgical approach. The flap was closed using interrupted sutures. The old denture was relieved and lined with a soft liner (Permaflex; Kohler, Neuhausen, Germany). After three months, the implants were uncovered, and healing abutments were connected. After 2 weeks, open tray impression procedure was started. Preliminary impressions were made with irreversible hydrocolloid material and poured to obtain a diagnostic cast on which custom trays were fabricated with an open area in the mandibular tray in implant region using autopolymerizing acrylic resin. Impression transfer copings with long screws were threaded into the implants ${ }^{38}$. After border molding of the trays, the impression of the ridges was made using medium body rubber base impression material (Zhermack, Rovigo, Vêneto, Italy). Light-body material was injected around the impression copings while applying finger pressure to the distal portion of the tray. The transfer copings were splinted to the polished surface of the tray with autopolymerizing acrylic resin ${ }^{39}$ to avoid 
movements of the copings. The copings were then unthreaded and implant analogs were attached to the impression coping with the long fixation screw and the final impressions were poured with stone. Bar abutments (Dentaurum, Germany) were screwed into the implant analogs and the implants were connected with a resilient bar (OT bar multiuse ${ }^{\circledR}$, RHEIN 83, Italy) plastic pattern leaving $1.5 \mathrm{~mm}$ space between the bar and the ridge. Two short distal cantilevers of $7 \mathrm{~mm}$ lengths were added to the bar. The bar was invested and casted into cobalt chromium alloy. The bar was tested for passivity in patient mouth using single screw test (Fig 1a- CHB group). Record bases were constructed and used to make jaw relations. Shallow cusp acrylic resin teeth (Vitapan®,Vita Zahnfabrik, Bad Säckingen, Germany) were used and the functional masticatory concept was a bilateral balanced occlusion. The dentures were processed in the usual manner. Three plastic clips were placed in their metal housings and placed over the bar. One plastic clip was placed over the bar and one clip was placed on each cantilever. The clips and housings were picked up intraorally to the fitting surface of the dentures using self-

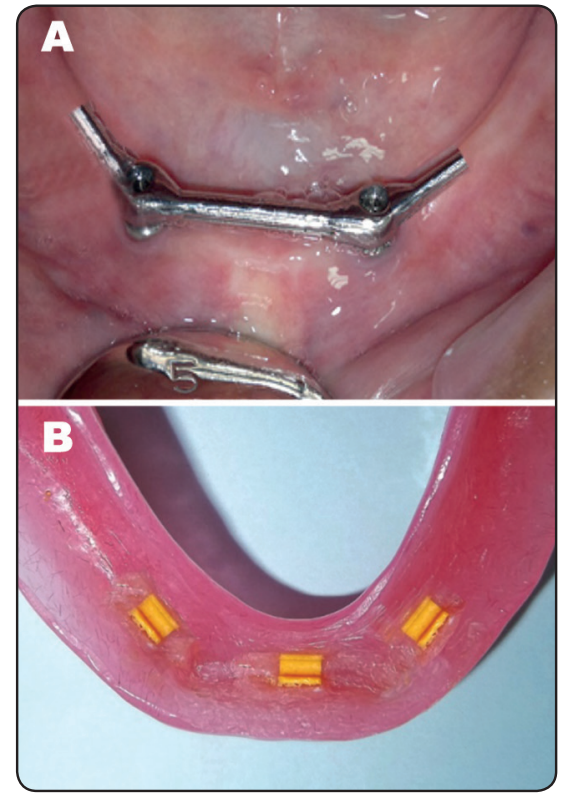

Fig. (1) Cantilevered Hader bar (CHB), a, intraoral view, b fitting surface of the overdenture with 3 plastic clips cure acrylic resin (Fig. 1b) to obtain passive fit. The dentures were delivered to the patients after performing border and occlusal adjustments. The participants were allowed to wear the dentures for 3 months to enhance neuromuscular adaptation. After measurements of chewing efficiency and bite force, the cantilevers of the bar were sectioned by a metal disc, and clips on the cantilevers were removed (fig $2 b$ ). The denture base was relined, the anterior plastic clip was replaced and the patient was allowed to use the denture for another 3 months and the chewing efficiency and bite force were measured again.

\section{Measurement of chewing efficiency}

Evaluation of chewing efficiency was made using the 2 -colored chewing gum ${ }^{34,35}$. Two pieces (30 18x $\times 3 \mathrm{~mm}$ ) in size of Gum of 2 colors; one with mint flavor (white) and the other with Strawberry flavor (red) were placed over each other. The patients were instructed to chew 5 samples of the gum for 5, 10, 20, 30 , and 50 masticatory cycles. One minute recovery period was interposed between each masticatory strokes to minimize fatigue of masticatory muscles.

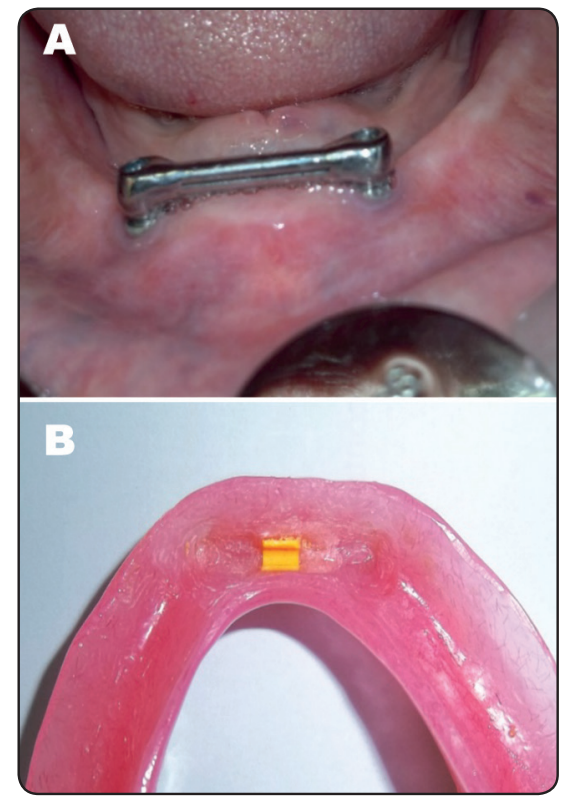

Fig. (2) Hader bar without cantilevers (HB), a, intraoral view, $\mathrm{b}$ fitting surface of the overdenture with 1 plastic clip 
The masticated gums were spat and flattened to $1 \mathrm{~mm}$ thickness in plastic bags. The gums were then scanned from both sides with resolution of 600 dots per inch. The Adobe Photoshop ${ }^{\circledR}$ program was used for image analysis. The image size was standardized at $1175 \times 925$ pixels and saved in Adobe Photoshop ${ }^{\circledR}$ format (*.psd). Then the 'magic wand' tool and "histogram" tool of the program were used to select the unmixed red pixels of the image (fig 3). The numbers of pixels were detected from the histogram for each side and the mean was used. Then, a ratio was computed for the Unmixed Fraction (UF) using the following equation:

(Pixels ${ }_{\text {orange side a }}+$ Pixels ${ }_{\text {orange side b }}$ ) $-2 \times$ Pixels of scale

$$
2 \times \text { Pixels }_{\text {all }}
$$

Increased UF means a decrease in chewing efficiency and vice versa.

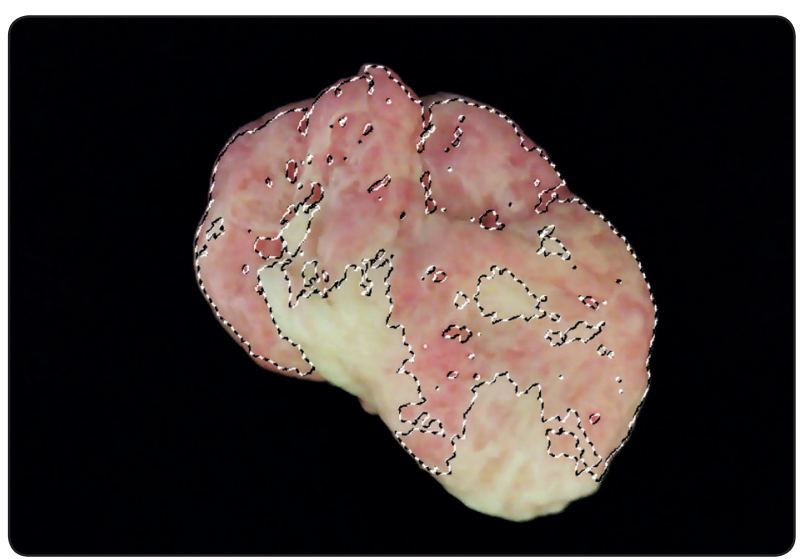

Fig. (3) Measurement of unmixed pixels using the magic wand tool of the Photoshop program.

\section{Measurements of maximum bite force}

Measurements of maximum bite forces were made with a bite-force transducer ${ }^{40}$ (GM10, Nagano Keiki, Tokyo, Japan). The device has a bite fork covered with a rubber protector on which the patient bites with maximum effort (fig 4). The device was inserted between the maxillary and mandibular teeth in the first molar regions and the patients were informed to bite as hard as possible on the bite-fork

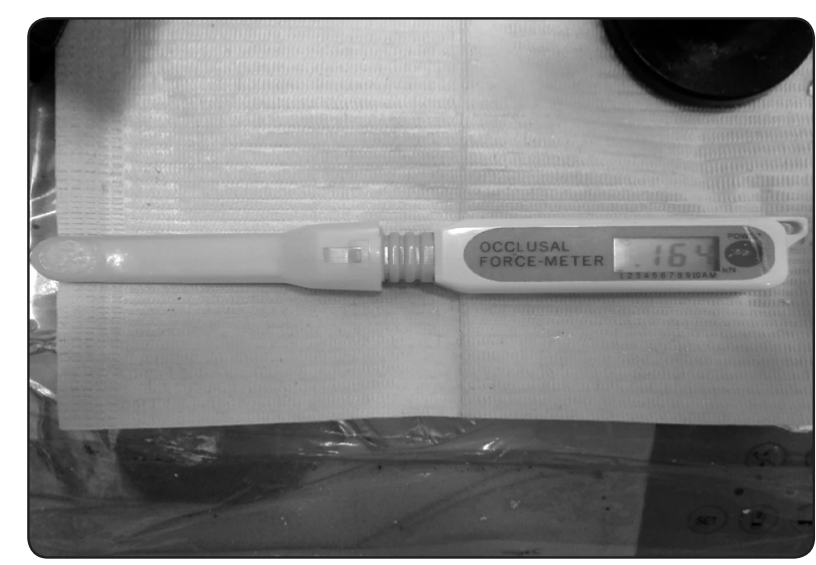

Fig. (4) Measurement of maximum bite force using a bite force transducer

for 7 seconds. The measurements were performed on each side 3 times after 5-minutes of rest and the mean was recorded for each patient. The highest bite force (in newton, N) was used.

Chewing efficiency and maximum bite force were measured 3 months after using each of the following dentures; conventional dentures (CD), cantilevered Hader bar overdentures (CHB), and non-cantilevered Hader bar overdentures (HB).

\section{Statistical analysis}

The Shapiro-Wilk test was used to assess the normality of data distribution since the sample size was small. The data was parametric and met the normal distribution. Two-way repeated-measures ANOVA was used to compare UF between dentures $(\mathrm{CD}, \mathrm{CHB}$, and $\mathrm{HB})$ and between masticatory strokes $(5,10,20,30$, and 50 cycles), followed by posthoc Bonferroni test for $\mathrm{W}$ pairwise comparisons. One way ANOVA was used to compare maximum bite force between dentures (CD, $\mathrm{CHB}$, and $\mathrm{HB})$. Statistical significance was set at .05 for all analyses.

\section{RESULTS}

Comparison of unmixed Fraction (UF) between different masticatory (chewing) strokes is presented in table 1. There was a significant difference 
between all chewing for all groups. The highest unmixed Fraction was noted with 5 cycles and the lowest number was noted with 50 cycles. For all groups, unmixed Fraction decreased with the increase of number of chewing strokes. Multiple pairwise comparison revealed insignificant differences between 5 and 10 cycles and between 20 and 30 cycles. However there was a significant difference between 10 and 20 cycles, and between the 50 cycles and all other cycles $(5,10,20,30)$.

Comparison of UF between groups is presented in table 1. There were significant differences between all groups for all chewing strokes. For all chewing strokes, the highest UF was noted with CD, followed by $\mathrm{HB}$, and the lowest UF was noted with CHB. Multiple pairwise comparison of UF between each of 2 groups is presented in table 2 and in fig5. At 5, 10, and 20 cycles, CD showed significant higher UF than $\mathrm{HB}$ and $\mathrm{CHB}$, but no significant difference was noted between $\mathrm{HB}$ and CHB. At 30 and 50 strokes, there was a significant difference between each 2 groups, and HB showed significant higher UF than CHB.

TABLE (1) Comparison of unmixed Fraction (UF) between different groups and different masticatory (chewing) strokes

\begin{tabular}{|c|c|c|c|c|c|c|c|}
\hline & \multicolumn{2}{|c|}{ CD } & \multicolumn{2}{|c|}{ СНB } & \multicolumn{2}{|c|}{ HB } & \multirow[t]{2}{*}{ ANOVA } \\
\hline & $X$ & $S D$ & $X$ & $S D$ & $X$ & $S D$ & \\
\hline $5 \mathrm{CS}$ & $.6813 a$ & .0065 & $.6084 a$ & .0011 & $.6145 \mathrm{a}$ & .0048 & $.001 *$ \\
\hline $10 \mathrm{CS}$ & $.6782 \mathrm{a}$ & .0076 & $.6032 \mathrm{a}$ & .0017 & $.6085 a$ & .0038 & $.001 *$ \\
\hline $20 \mathrm{CS}$ & $.6632 b$ & .0023 & $.5895 \mathrm{~b}$ & .0026 & $.5956 b$ & .0040 & $.003^{*}$ \\
\hline $30 \mathrm{CS}$ & $.6608 b$ & .0122 & $.5615 b$ & .0255 & $.5868 \mathrm{~b}$ & .0038 & $.002 *$ \\
\hline $50 \mathrm{CS}$ & $.6390 \mathrm{c}$ & .0068 & $.5125 \mathrm{~d}$ & .0049 & $.5504 \mathrm{c}$ & .0037 & $<.001^{*}$ \\
\hline Repeated ANOVA & \multicolumn{2}{|c|}{$.001 *$} & \multicolumn{2}{|c|}{$.004 *$} & \multicolumn{2}{|c|}{$.003 *$} & \\
\hline
\end{tabular}

$X$; mean, SD; CS; chewing strokes, CD; complete denture, CHB; cantilevered Hader bar, HB, Hader bar without cantilevers, *; $P$ is significant at 5\%. Different letters in the same column represent significant difference between each 2 numbers of chewing strokes (Bonferroni test, $P$ is <.05). The same letters indicate no significant difference between 2 numbers of chewing strokes

Table 2: Multiple comparisons of UF between each two groups at different numbers of chewing strokes

\begin{tabular}{|c|c|c|c|c|c|}
\hline \multirow{2}{*}{$\begin{array}{c}\text { Multiple comparisons } \\
\text { between each two groups }\end{array}$} & \multicolumn{5}{|c|}{ Bonnferoni post hoc test (P-value) } \\
\cline { 2 - 6 } & $5 \mathrm{CS}$ & $10 \mathrm{CS}$ & $20 \mathrm{CS}$ & $30 \mathrm{CS}$ & $50 \mathrm{CS}$ \\
\hline CD-CHB & .001 & .002 & .001 & .007 & .001 \\
\hline CD-HB & .001 & .003 & .004 & .001 & .004 \\
\hline CHB_HB & .260 & .385 & .260 & .001 & .002 \\
\hline
\end{tabular}




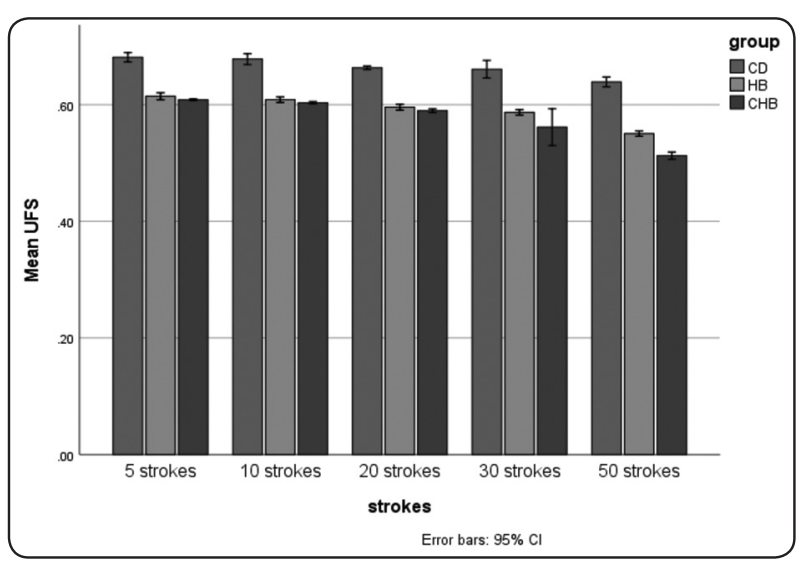

Fig. (5) Multiple comparisons of UF (unmixed fractions) between each 2 groups at different numbers of chewing strokes.

Comparison of maximum bite force between groups is presented in table 3 . There was a significant difference in the maximum bite force between groups. The highest maximum bite force was noted with $\mathrm{CHB}$, followed by $\mathrm{HB}$, and the lowest was noted with $\mathrm{CD}$.

TABLE (3) Comparison of maximum bite force between groups

\begin{tabular}{|c|c|c|c|c|}
\hline & CD & CHB & HB & ANOVA \\
\hline $\mathbf{X}$ & $73.00 \mathrm{a}$ & $103.57 \mathrm{~b}$ & $95.17 \mathrm{c}$ & \multirow{2}{*}{$\mathrm{p}<.001^{*}$} \\
\cline { 1 - 4 } SD & 5.40 & 6.85 & 7.65 & \\
\cline { 1 - 4 } M & 73.00 & 102.00 & 94.00 & \\
\cline { 1 - 4 } Min & 65.00 & 95.00 & 85.00 & \\
\cline { 1 - 4 } Max & 80.00 & 115.00 & 105.00 & \\
\hline
\end{tabular}

CD; complete denture, CHB; cantilevered Hader bar, $H B$, Hader bar without cantilevers, *; $P$ is significant at $5 \%$. Different letters in the same raw represent significant difference between each 2 groups (Bonferroni test, $P$ is $<.05$ ).

\section{DISCUSSION}

The within subjects study design used in this trial help to control several confounding factors that may affect the chewing efficiency and maximum bite force measurements. The same patient received different types of prostheses $(\mathrm{CD}, \mathrm{CHB}$, and $\mathrm{HB}$ ) which make it easy to control for anatomical factors such as muscle power and tone, muscle activity, residual ridge anatomy, arch relationship, patient age, and gender. All these variables are standardized between different prostheses ${ }^{34}$. Moreover, the crossover study design allows using of a small sample size thus reducing the number of the patient's and the total cost of the study. The use of two different colors of masticatory gum in the evaluation of masticatory efficiency was approved to be an efficient and reliable measurement in other studies ${ }^{34,35,41}$. This method provides several advantages like simplicity and cost-effectiveness compared to other methods for example the sieving method. Furthermore, the high color mixing easily demonstrates increased masticatory efficiency due to leaching out of the sweetening components. Also, masticatory gum prevents stagnation of food particles under the dentures or swallowing of these particles and thus may be lost and not evaluated ${ }^{42}$.

In this study, the highest unmixed Fraction was noted with 5 cycles and the lowest number was noted with 50 cycles. For all groups, unmixed Fraction decreased with the increase in the number of chewing strokes. This indicates higher degree of mixing of the colors of the gum by increasing the number of chewing strokes due to the extraction of sweetening components and higher mixing ability of the patient's which increased by the increasing number of chewing strokes as stated in another study ${ }^{35}$. A similar observation was also noted in other studies $^{34,43}$ which compared masticatory efficiency of mandibular implant overdentures retained by different attachments.

For all chewing strokes, the highest UF was noted with $\mathrm{CD}$, followed by $\mathrm{HB}$, and the lowest UF was noted with CHB. The increased chewing efficiency provided by the bar-retained implant overdentures (whether cantilevered or noncantilevered) as compared to conventional dentures 
is in line with several studies ${ }^{37,44-46}$ and could be attributed to the enhancement of stability and retention of the overdentures by means of implants and attachments which consequently improve oral function as compared with conventional complete dentures $^{37,44-48}$. On the other hand, conventional denture in patients with atrophied ridge has reduced masticatory ability due to the instability of the denture and the pain from pressure on sensitive mandibular mucosa during mastication due to compression of the tissues and shifting of the denture. These are considered limiting factors for achieving good muscle action. Therefore patients with conventional dentures are unable to use the full power of masticatory muscles during the biting and chewing $^{49}$. On the contrary, implant overdentures improved the muscular activity and enhance unrestricted mandibular excursions ${ }^{50}$, provide stabilization of the occlusal plane, and improve the patient satisfaction and comfort during chewing ${ }^{51}$. These factors encourage the patient's to exhibit the more bite force, therefore food comminution is more effective. The efficacy of implant overdentures in improving chewing efficiency was reported by Feine et $\mathrm{al}^{32}$ who found that these overdentures lose only $10 \%$ of chewing efficiency compared with natural teeth and stated that implant overdenture was not less efficient than a fixed prosthesis with respect to masticatory function.

Comparing the groups together $\mathrm{CHB}$ was associated with significant higher chewing efficiency than HB after 30 and 50 strokes. This could be attributed to the increased support stability and retention of $\mathrm{CHB}$ provided by the cantilever extensions. The presence of cantilever allows increasing the number of retentive clips from one (as in the HB group) to three (as in the CHB group). This increases the friction and retention forces. In agreement with these findings, Botega et $\mathrm{al}^{52}$ found that $\mathrm{CHB}$ attachment showed significantly higher initial and final retention values than the other retention systems (Conexao/O-ring and Lifecore/Oring attachments). The increased stability of $\mathrm{CHB}$ may be due to plastic clips firmly grip the bar and prevent denture rotation and lateral movements during mastication. The increased denture supposed, stability and retention produce more comfort during mastication and make the patient exert more muscle power with increased chewing efficiency. In contrast, overdentures in HB groups are totally resilient and rotates around an imaginary line that pass through the long axis of the bar and also move side to side during mastication. Also the overdentures are supported by mucosa posteriorly ${ }^{53}$. These movements may produce discomfort and pain during mastication and may be responsible for reduced masticatory efficiency compared to CHB.

The highest maximum bite force was observed was CHB followed by HB and the lowest maximum bite force was noted with $\mathrm{CD}$. The increased bite force with $\mathrm{CHB}$ and HB may be attributed to the enhanced stability and retention of the dentures by implants as stated previously which produce more masticatory muscle activity, improve patient satisfaction and minimize pain during chewing 30, 54. Similarly, several authors 45, 55, 56 reported improvement of the average maximum bite force after implant overdenture treatment.

The increased maximum bite force with $\mathrm{CHB}$ compared to HB may be attributed to the good retention and stability obtained by the cantilever extensions and the increased number of clips as stated previously. In $\mathrm{CHB}$, the overdentures are more rigid and did not rotate freely during function as overdentures in HB group do during functional loading of mandibular overdenture ${ }^{57}$ thus achieving more comfort during biting.

The limitations of this study include a small sample size and short period of denture use. Longerterm randomized trials with larger samples are needed to support or confirm the findings of this study. Also, different types of bar and clip designs are needed to be tested such as Dolder (oval) bars and metal clips or milled (rectangular) bars and metal housing. 


\section{CONCLUSION}

Within the limitations of this study, it could be concluded that both cantilevered and noncantilevered bar attachments for 2 implant overdentures achieved higher chewing efficiency and maximum bite force than conventional dentures in patients with atrophied mandibular ridges. However, cantilevered bar was associated with significant higher chewing efficiency and maximum bite force compared to non-cantilevered bar.

\section{REFERENCES}

1. Al-Ghafli SA, Michalakis KX, Hirayama H, Kang K. The in vitro effect of different implant angulations and cyclic dislodgement on the retentive properties of an overdenture attachment system. J Prosthet Dent 2009; 102: 140-147.

2. van Waas MA. The influence of clinical variables on patients' satisfaction with complete dentures. J Prosthet Dent 1990; 63: 307-310.

3. Feine JS, Carlsson GE, Awad MA, Chehade A, Duncan WJ, Gizani S, Head T, Heydecke G, Lund JP, MacEntee M, Mericske-Stern R, Mojon P, Morais JA, Naert I, Payne AG, Penrod J, Stoker GT, Tawse-Smith A, Taylor TD, Thomason JM, Thomson WM, Wismeijer D. The McGill consensus statement on overdentures. Mandibular twoimplant overdentures as first choice standard of care for edentulous patients. Gerodontology 2002; 19: 3-4.

4. Thomason JM, Feine J, Exley C, Moynihan P, Muller F, Naert I, Ellis JS, Barclay C, Butterworth C, Scott B, Lynch C, Stewardson D, Smith P, Welfare R, Hyde P, McAndrew R, Fenlon M, Barclay S, Barker D. Mandibular two implant-supported overdentures as the first choice standard of care for edentulous patients--the York Consensus Statement. Br Dent J 2009; 207: 185-186.

5. Kobayashi M, Srinivasan M, Ammann P, Perriard J, Ohkubo C, Muller F, Belser UC, Schimmel M. Effects of in vitro cyclic dislodging on retentive force and removal torque of three overdenture attachment systems. Clin Oral Implants Res 2014; 25: 426-434.

6. Heckmann SM, Winter W, Meyer M, Weber HP, Wichmann MG. Overdenture attachment selection and the loading of implant and denture-bearing area. Part 1: In vivo verification of stereolithographic model. Clin Oral Implants Res 2001; 12: 617-623.
7. Carpentieri JR. Clinical protocol for an overdenture bar prosthesis fabricated with CAD/CAM technology. Pract Proced Aesthet Dent 2004; 16: 755-757.

8. Kurtzman GM. The locator attachment: free-standing versus bar-overdentures. . Dental Labor International Plus 2009: 20-23. .

9. Heckmann SM, Winter W, Meyer M, Weber HP, Wichmann MG. Overdenture attachment selection and the loading of implant and denture-bearing area. Part 2: A methodical study using five types of attachment. Clin Oral Implants Res 2001; 12: 640-647.

10. Elkerdawy MW, Radi IA. Effect of dislodging forces on mandibular implant attachment-retained overdenture. Implant Dent 2011; 20: 246-254.

11. Sadowsky SJ. Mandibular implant-retained overdentures: a literature review. J Prosthet Dent 2001; 86: 468-473.

12. Burns DR. Mandibular implant overdenture treatment: consensus and controversy. J Prosthodont 2000; 9: 37-46.

13. Federick DR, Caputo AA. Effects of overdenture retention designs and implant orientations on load transfer characteristics. J Prosthet Dent 1996; 76: 624-632.

14. Rudd K, Morrow R, HF E. Dental laboratory procedures: Removable partial denture. The C.V. Mosby Company St. Louis. Toronto. London. 1981.

15. Walton JN, Ruse ND. In vitro changes in clips and bars used to retain implant overdentures. J Prosthet Dent 1995; 74: 482-486.

16. Duyck J, Van Oosterwyck H, Vander Sloten J, De Cooman M, Puers R, Naert I. In vivo forces on oral implants supporting a mandibular overdenture: the influence of attachment system. Clin Oral Investig 1999; 3: 201-207.

17. Skalak R. Biomechanical considerations in osseointegrated prostheses. J Prosthet Dent 1983; 49: 843-848.

18. Jacobs R, Schotte A, van Steenberghe D, Quirynen M, Naert I. Posterior jaw bone resorption in osseointegrated implant-supported overdentures. Clin Oral Implants Res 1992; 3: 63-70.

19. Mericske-Stern R. Force distribution on implants supporting overdentures: the effect of distal bar extensions. A 3-D in vivo study. Clin Oral Implants Res 1997; 8: 142-151.

20. Sadowsky SJ, Caputo AA. Stress transfer of four mandibular implant overdenture cantilever designs. J Prosthet Dent 2004; 92: 328-336. 
21. Cekic C, Akca K, Cehreli MC. Effects of attachment design on strains around implants supporting overdentures. Quintessence Int 2007; 38: e291-297.

22. Elsyad MA, Al-Mahdy YF, Salloum MG, Elsaih EA. The effect of cantilevered bar length on strain around two implants supporting a mandibular overdenture. Int J Oral Maxillofac Implants 2013; 28: e143-150.

23. Elsyad MA, Alokda MM, Gebreel AA, Hammouda NI, Habib AA. Effect of two designs of implant-supported overdentures on peri-implant and posterior mandibular bone resorptions: a 5-year prospective radiographic study. Clinical oral implants research 2017; 28: e184-e192.

24. Krennmair G, Krainhofner M, Piehslinger E. The influence of bar design (round versus milled bar) on prosthodontic maintenance of mandibular overdentures supported by 4 implants: a 5-year prospective study. Int J Prosthodont 2008; 21: 514-520.

25. Mericske-Stern RD, Taylor TD, Belser U. Management of the edentulous patient. Clin Oral Implants Res 2000; 11 Suppl 1: 108-125.

26. Mericske-Stern R, Piotti M, Sirtes G. 3-D in vivo force measurements on mandibular implants supporting overdentures. A comparative study. Clin Oral Implants Res 1996; 7: 387-396.

27. Misch CE. Treatment Options for Mandibular Implant Overdentures in: Misch CE, Bidez MW, Judy KWM et al, eds Dental implant prosthetics. 3nd ed. St. Louis: Mosby 2005: 218-235.

28. de Jong MH, Wright PS, Meijer HJ, Tymstra N. Posterior mandibular residual ridge resorption in patients with overdentures supported by two or four endosseous implants in a 10-year prospective comparative study. Int J Oral Maxillofac Implants 2010; 25: 1168-1174.

29. Oetterli M, Kiener P, Mericske-Stern R. A longitudinal study on mandibular implants supporting an overdenture: the influence of retention mechanism and anatomic-prosthetic variables on periimplant parameters. Int J Prosthodont 2001; 14: 536-542.

30. Slagter AP, Bosman F, van der Glas HW, van der Bilt A. Human jaw-elevator muscle activity and food comminution in the dentate and edentulous state. Arch Oral Biol 1993; 38: 195-205.

31. Schimmel M, Leemann B, Herrmann FR, Kiliaridis S, Schnider A, Muller F. Masticatory function and bite force in stroke patients. J Dent Res 2011; 90: 230-234.
32. Feine JS, Maskawi K, de Grandmont P, Donohue WB, Tanguay R, Lund JP. Within-subject comparisons of implant-supported mandibular prostheses: evaluation of masticatory function. J Dent Res 1994; 73: 1646-1656.

33. Feine JS, Lund JP. Measuring chewing ability in randomized controlled trials with edentulous populations wearing implant prostheses. J Oral Rehabil 2006; 33: 301-308.

34. Elsyad MA, Hegazy SA, Hammouda NI, Al-Tonbary GY, Habib AA. Chewing efficiency and electromyographic activity of masseter muscle with three designs of implantsupported mandibular overdentures. A cross-over study. Clin Oral Implants Res 2014; 25: 742-748.

35. Schimmel M, Christou P, Herrmann F, Muller F. A twocolour chewing gum test for masticatory efficiency: development of different assessment methods. J Oral Rehabil 2007; 34: 671-678.

36. van der Bilt A, van Kampen FM, Cune MS. Masticatory function with mandibular implant-supported overdentures fitted with different attachment types. Eur J Oral Sci 2006; 114: 191-196.

37. van Kampen FM, van der Bilt A, Cune MS, FontijnTekamp FA, Bosman F. Masticatory function with implantsupported overdentures. J Dent Res 2004; 83: 708-711.

38. Zarb GA, Jansson T. Prosthodontic procedures. In: Brånemark, P.I., Zarb, G.A., Albrektsson, T. eds. Tissue Integrated Prostheses - Osseointegration in Clinical Dentistry. p. 251-270 1985; Quintessence Publishing Co. Inc. Chicago, United States of America.

39. Gregory-Head B, LaBarre E. Two-step pick-up impression procedure for implant-retained overdentures. J Prosthet Dent 1999; 82: 615-616.

40. Fernandes CP, Glantz PO, Svensson SA, Bergmark A. A novel sensor for bite force determinations. Dent Mater 2003; 19: 118-126.

41. Anastassiadou V, Heath MR. The development of a simple objective test of mastication suitable for older people, using chewing gums. Gerodontology 2001; 18: 79-86.

42. Liedberg B, Owall B. Oral bolus kneading and shaping measured with chewing gum. Dysphagia 1995; 10: 101106.

43. Elsyad MA, Khairallah AS. Chewing efficiency and maximum bite force with different attachment systems of implant overdentures: a crossover study. Clin Oral Implants Res 2017; 28: 677-682. 
44. van der Bilt A, Speksnijder CM, de Liz Pocztaruk R, Abbink JH. Digital image processing versus visual assessment of chewed two-colour wax in mixing ability tests. J Oral Rehabil 2012; 39: 11-17.

45. Bakke M, Holm B, Gotfredsen K. Masticatory function and patient satisfaction with implant-supported mandibular overdentures: a prospective 5-year study. Int J Prosthodont 2002; 15: 575-581.

46. Toman M, Toksavul S, Saraçog `lu A, Cura C, Hatipog `lu A. Masticatory Performance and Mandibular Movement Patterns of Patients with Natural Dentitions, Complete Dentures, and Implant-Supported Overdentures. . Int J Prosthodont 2012; 25: 135-137.

47. Farias Neto A, Pereira BM, Xitara RL, Germano AR, Ribeiro JA, Mestriner Junior W, Carreiro Ada F. The influence of mandibular implant-retained overdentures in masticatory efficiency. Gerodontology 2012; 29: e650-655.

48. Boven GC, Raghoebar GM, Vissink A, Meijer HJ. Improving masticatory performance, bite force, nutritional state and patient's satisfaction with implant overdentures: a systematic review of the literature. J Oral Rehabil 2015; 42: 220-233.

49. Caloss R, Al-Arab M, Finn RA, Throckmorton GS. The effect of denture stability on bite force and muscular effort. J Oral Rehabil 2011; 38: 434-439.

50. ElSyad MA, Ibrahim AE, Nawar NHH, Belal TM. Electromyographic Connectivity of Masseter Muscle with Different Retentive Attachments for Implant Overdentures in Patients with Atrophied Mandibular Ridges: A Crossover Study. Int J Oral Maxillofac Implants 2019; 34: 1213-1222.
51. Mahanna FF, Elsyad MA, Mourad SI, Abozaed HW. Satisfaction and Oral Health-Related Quality of Life of Different Attachments Used for Implant-Retained Overdentures in Subjects with Resorbed Mandibles: A Crossover Trial. Int J Oral Maxillofac Implants 2020; 35: 423-431.

52. Botega DM, Mesquita MF, Henriques GE, Vaz LG. Retention force and fatigue strength of overdenture attachment systems. J Oral Rehabil 2004; 31: 884-889.

53. Savabi O, Nejatidanesh F, Yordshahian F. Retention of implant-supported overdenture with bar/clip and stud attachment designs. J Oral Implantol 2013; 39: 140-147.

54. Diaz-Tay J, Jayasinghe N, Lucas PW, McCallum JC, Jones JT. Association between surface electromyography of human jaw-closing muscle and quantified food breakdown. Arch Oral Biol 1991; 36: 893-898.

55. Muller F, Hernandez M, Grutter L, Aracil-Kessler L, Weingart D, Schimmel M. Masseter muscle thickness, chewing efficiency and bite force in edentulous patients with fixed and removable implant-supported prostheses: a cross-sectional multicenter study. Clin Oral Implants Res 2012; 23: 144-150.

56. Elsyad MA, Khairallah AS. Chewing efficiency and maximum bite force with different attachment systems of implant overdentures: a crossover study. Clin Oral Implants Res 2017; 28: 677-682.

57. ELsyad MA, Errabti HM, Mustafa AZ. Mandibular Denture Base Deformation with Locator and Ball Attachments of Implant-Retained Overdentures. J Prosthodont 2016; 25: 656-664. 